\title{
Case Report: Fatigue and Bleeding in a Polymedicated Patient Using Several Herbal Supplementations, Detected with $\mathrm{g}-\mathrm{Nomic}{ }^{\circledR}$ Software
}

\author{
Abel Saldarreaga Marin (D) \\ Marc Cendros ${ }^{2}$ \\ Carlos J Ciudad (iD) ${ }^{3}$ \\ Ana Sabater (D) ${ }^{2}$ \\ 'Bahía de Cádiz-La Janda Health District, \\ Mobile Emergency Unit of the Andalusian \\ Health Care, Service of Cádiz, Cádiz, \\ Spain; ${ }^{2}$ Eugenomic, Barcelona, Spain; \\ ${ }^{3}$ Biochemistry and Molecular Biology \\ Unit, School of Pharmacy, University of \\ Barcelona, Barcelona, Spain
}

\begin{abstract}
This was a case report of severe fatigue and bleeding in a 65-year-old man with ischemic heart disease who was wearing a stent and taking multiple medications for hypertension and diabetes. The use of a drug interaction and personalized prescription software ( $\mathrm{g}$-Nomic ${ }^{\mathbb{R}}$ ) revealed potential interactions, involving acetylsalicylic acid and several non-pharmaceutical products including ginger, blueberry extracts, pineapple juice, docosahexaenoic acid and liquorice. Correction of these interactions resulted in complete remission of the reported side effects. This supports the idea that non-pharmaceuticals potentiated the effects of acetylsalicylic acid on haemostasis, producing the bleeding that would have caused fatigue. It is important to use appropriate tools to detect drug interactions that also take into account commonly used nonpharmaceutical products. Drug interactions can be considered illnesses by themselves.
\end{abstract}

Keywords: pharmacogenetics, SNP, drug-drug interaction, druglifestyle interactions, drug-herb, software, bleeding, fatigue, polymedication, medication risk, pharmacogenetics software, personalized prescription

\section{Introduction}

Drug treatment can be affected by significant variability in the degree of response and the occurrence of side effects. Adverse drug reactions are responsible for considerable morbidity and mortality. Sometimes these undesirable effects are intrinsic to the drug, but in many cases they are due to drug-drug interactions. ${ }^{1,2}$ It is known that drug-drug interactions can trigger adverse effects of medicines that would have been safe if they had not been used in combination. In addition, other substances that are not usually considered pharmaceuticals, like herbal products, may also cause drug-lifestyle interactions. Recognising and managing these interactions can be an invaluable process in achieving safer therapy.

We present a case of a polymedicated patient who was taking apparently harmless substances and dietary supplements and who presented with bleeding and fatigue. This situation was resolved by identifying and managing drug interactions using g-Nomic ${ }^{\circledR}$ personalised prescription software.

\section{Case Presentation}

A 65-year-old Caucasian man with hypertension, type 2 diabetes, elevated LDLcholesterol and ischemic cardiomyopathy, wearing a stent, presented unexplained fatigue with physical activity and coagulation defects consisting of gingival bleeding and frequent bruising.
Correspondence: Ana Sabater Eugenomic, c/ Londres 6, Barcelona, 08029, Spain

Tel +34-93-292-2963

Email asabater@eugenomic.com 


\section{Analytical Explorations}

All biochemical parameters were within the normality except for elevated LDL-c levels. Hepatic and renal functions were normal (Alanine transaminase -ALT $17 \mathrm{U} / \mathrm{L}$, aspartate transaminase AST $21 \mathrm{u} / \mathrm{L}$, gammaglutamyltransferase $24 \mathrm{U} / \mathrm{L}$, creatinine $0.94 \mathrm{mg} / \mathrm{dL}$, blood urea $35 \mathrm{mg} / \mathrm{dL}$, glucose $95 \mathrm{mg} / \mathrm{dL}$, glycosylated haemoglobin 6.1\%). Prothrombin time (seconds): 10.2“ (8.9-13.3). Normalized prothrombin time (INR): $0.90(0.80-1.20)$.

At the moment of the consultation, the patient had the following treatment:

Telmisartan 40mg/d, metformin $850 \mathrm{mg} / \mathrm{d}$, empagliflozin $40 \mathrm{mg} / \mathrm{d}$, bisoprolol $2.5 / \mathrm{d}$, atorvastatin $40 \mathrm{mg} / \mathrm{d}$, clopidogrel $75 \mathrm{mg} / \mathrm{d}$ and acetylsalicylic acid (ASA) $100 \mathrm{mg} / \mathrm{d}$.

\section{Examination}

Except for fatigue and bleeding, the patient showed good general condition; he was conscious, oriented and collaborative, eupnoeic at rest and afebrile. Cardiopulmonary auscultation and abdominal examination did not result in pathological findings. Basal oxygen saturation: 98\%. Blood pressure: $138 \mathrm{~mm} \mathrm{Hg}$ (systolic)/76 mm Hg (diastolic). Heart rate; $85 \mathrm{bpm}$. Respiratory rate at rest: $14 \mathrm{bpm}$. Temperature: $35.8^{\circ} \mathrm{C}$.

The patient's medication regime was evaluated using g-Nomic ${ }^{\circledR}$ software ${ }^{3}$ to check for interactions and possible genetic effects. In Figure 1 it is shown all the initial drugs entered in the personalized prescription software.

In addition, the same personalized prescription software was used to check for possible substances that could contribute to interactions even if they are not considered drugs per se, referred to in the software as lifestyle habits. After interviewing the patient about them, it was identified that the patient consumed 3 grams of docosahexaenoic acid (DHA) /day, blueberry and ginger extract supplements, and daily consumption of pineapple juice. In addition, the patient quit smoking nine years ago, and since then has been consuming liquorice ever since to support abstinence. Figure 2 shows the list of lifestyle

\section{My Patients}

\section{Add Active Ingredient (A)}

Name Surname

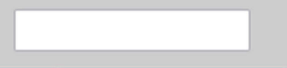

Med.history Num/Ref. Patient

\begin{tabular}{|c|c|c|c|c|c|}
\hline Active ingredient & Brand name drug & $\begin{array}{l}\text { Medication } \\
\text { start }\end{array}$ & $\begin{array}{l}\text { Medication } \\
\text { end }\end{array}$ & Stop tacking & $\begin{array}{l}\text { Delete/ } \\
\text { Stop taking }\end{array}$ \\
\hline Acetylsalicilic acid & & 31.05 .2021 & N/A & $\square$ & $\begin{array}{l}\text { Delete } \\
\text { Stop taking }\end{array}$ \\
\hline Atorvastatin & & 31.05 .2021 & N/A & $\square$ & $\begin{array}{l}\text { Delete } \\
\text { Stop taking }\end{array}$ \\
\hline Bisoprolol & & 31.05 .2021 & N/A & $\square$ & $\begin{array}{l}\text { Delete } \\
\text { Stop taking }\end{array}$ \\
\hline Clopidogrel & & 31.05 .2021 & N/A & $\square$ & $\begin{array}{l}\text { Delete } \\
\text { Stop taking }\end{array}$ \\
\hline Empagliflozin & & 31.05 .2021 & N/A & $\square$ & $\begin{array}{l}\text { Delete } \\
\text { Stop taking }\end{array}$ \\
\hline Metformin & & 31.05 .2021 & N/A & $\square$ & \begin{tabular}{|l} 
Delete \\
Stop taking
\end{tabular} \\
\hline Telmisartan & & 31.05 .2021 & N/A & $\square$ & \begin{tabular}{|l} 
Delete \\
Stop taking
\end{tabular} \\
\hline
\end{tabular}

Add Active Ingredient (AD) 


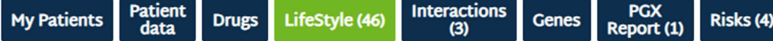

\begin{tabular}{|c|c|c|}
\hline \multicolumn{2}{|l|}{ Lifestyle } & \multirow[t]{2}{*}{$1-20$ of $46>\odot$} \\
\hline Surname & Med.history Num/Ref. & \\
\hline Active ingredient to & Verify interaction t* & \\
\hline Alcohol (Etanol) & Verify interaction & \\
\hline Aloe vera (Aloe barbadensis) & Verify interaction & \\
\hline Alpha-Lipoic Acid (ALA) & Verify interaction & \\
\hline Aluminum & Verify interaction & \\
\hline Arginine (Arginine) & Verify interaction & \\
\hline Astragalus & Verify interaction & \\
\hline Berberine (Berberis sp.) & See PGX Report tab to see interaction & \\
\hline Black pepper (Piper nigrum) & See PCX Report tab to see interaction & \\
\hline Blond plantain (Plantago ovata) & Verify interaction & \\
\hline Blueberry (Vaccinium corymbosum, v. myrtillus) & Verify interaction & \\
\hline Cat's claw (Uncaria tomentosa) & Verify interaction & \\
\hline Chamomile (Matricaria chamomilla) & See PGX Report tab to see interaction & \\
\hline Cinnamon (Cinnamomum verum) & Verify interaction & \\
\hline Danshen (Salvia miltiorrhiza) & Verify interaction & \\
\hline Embli (Phyllanthus emblica) & Verify interaction & \\
\hline Feverfew (Tanacetum parthenium) & Verify interaction & \\
\hline Filipendula ulmaria & Verify interaction & \\
\hline Ginger (Zingiber officinale) & Verify interaction & \\
\hline Ginkgo biloba-leaf extracts & Verify interaction & \\
\hline Grapefruit (Citrus paradisi) & Verify interaction & \\
\hline Horse-chestnut (Aesculus hippocastanum) & Verify interaction & \\
\hline Karela (Momordica charantia) & Verify interaction & \\
\hline Licorice (Glycyrrhiza glabra) & Verify interaction & \\
\hline Linum usitatissimum & Verify interaction & \\
\hline Methylthioninium chloride & See PGX Report tab to see interaction & \\
\hline Milk thistle (Silybum marianum) & See PGX Report tab to see interaction & \\
\hline Noni (Morinda citrifolia) & Verify interaction & \\
\hline Oats bran (Avena sativa) & Verify interaction & \\
\hline Omega 3 fatty acids & Verify interaction & \\
\hline Pectin & Verify interaction & \\
\hline Pine bark & Verify interaction & \\
\hline Pineapple -juice & See PGX Report tab to see interaction & \\
\hline Potasium & Verify interaction & \\
\hline Primrose oil (Oenothera spp.) & Verify interaction & \\
\hline Quinine & See PGX Report tab to see interaction & \\
\hline Red Clover (Trifolium pratense) & See PGX Report tab to see interaction & \\
\hline Red raspberry (Rubus idaeu) & See PGX Report tab to see interaction & \\
\hline Resveratrol & Verify interaction & \\
\hline Saint John's Wort (Hypericum perforatum) & Verify interaction & \\
\hline Schisandra (Schisandra chinensis) & See PGX Report tab to see interaction & \\
\hline Sulfisoxazole & See PGX Report tab to see interaction & \\
\hline Tamarind (Tamarindus indica) & Verify interaction & \\
\hline Turmeric (Curcuma longa) & See PGX Report tab to see interaction & \\
\hline Vitamin B3 (niacin) & Verify interaction & \\
\hline Willow Bark & Verify interaction & \\
\hline Xiaoke Pill & Verify interaction & \\
\hline
\end{tabular}

Figure 2 Shows the list of all lifestyle habits that could interact with patient's medication, reported by the personalized prescription software. 
habits that may interact negatively with the patient's prescription entered into the personalized prescription software. The physician should ask the patient if he/she takes any of these substances on a regular basis in his/her daily life. If so, the doctor should click on the hyperlink to make this lifestyle habits part of the prescription as a whole.

\section{Actions and Outcome}

After evaluating the possible interactions between medication and lifestyle, some measures were taken to avoid those interactions. Figure 3 shows drug-drug interactions as well as drug- lifestyle interactions. Figure 4 shows the possible interactions due to inhibitions and inductions caused by patient's polymedication. It is known that substances with inhibitory capacity can also impair enzyme activity even in the absence of loss-of-function variants. Therefore, a person who would be classified as a normal metaboliser based on a genetic test alone would experience a phenoconversion to a poor metaboliser when exposed to a strong inhibitor. Similarly, enzyme inducers can increase enzyme activity beyond what a genetic test might indicate. This reasoning can be extended to drug-herb and druglifestyle interactions as potential modulators of drug metabolism and thus drug response.

The patient was advised to discontinue the consumption of ginger, blueberry extracts and pineapple juice. The dose of omega-3 fatty acids was reduced from $3 \mathrm{~g} /$ day DHA to $1 \mathrm{~g} /$ day. Liquorice was maintained, but the patient was told to minimize its use.

As the patient was already being treated with a betablocker to control blood pressure, telmisartan was temporarily discontinued to minimise the side effects of the combination of two antihypertensive drugs.

Figure 5 shows the primary genes to be considered when checking the specific medication for to this clinical case. After assessing all drug interactions, no genetic testing of the patient was considered necessary.

The patient was scheduled for a follow-up evaluation two months later.

At the next visit, there was a clear improvement in both his clinical condition and general wellbeing. The coagulation defects had disappeared with no further gingival bleeding or skin bruising.

Blood pressure was normal (BP: 134/68 $\mathrm{mmHg}$ ) despite the discontinuation of telmisartan, and it was considered that reinstating the antihypertensive was not justified. Furthermore, glycaemia was also correct (HbAlc:
5.4\%) and it was decided to discontinue metformin leaving only Empagliflozin to manage the patient's diabetes.

The patient's general condition and well-being had also increased enormously: he did not complain of fatigue and had started exercising outdoors and working out at the gym three times a week.

\section{Discussion}

Drug interactions seem to have been the cause of the patient's worsening condition, as the improvement was remarkable after addressing the detected potential risks of interactions.

The main concern in this patient was the excessive bleeding. Several factors could have contributed to altered haemostasis, including impaired renal function, which could also explain the increased blood pressure. ASA has an anticoagulant action and may also reduce renal function, contributing to both said problems, and its effects could have been potentiated by other substances. Ginger has hypoglycaemic action, but has also been reported to inhibit thromboxane synthesis, so it may potentially interact with acetylsalicylic acid to potentiate the effects of this drug. ${ }^{4}$ Berries from the Vaccinium genus contain small amounts of salicylates, and berry juice in large quantities (more than $1 \mathrm{~L} /$ day) or berry extracts may increase the hypoprothrombinaemia effects of acetylsalicylic acid. ${ }^{5}$ While $1 \mathrm{~L}$ a day is too large to be a likely cause of interaction, the patient was taking an extract supplement, which usually contains higher amounts of active compounds than those present on juice or the berry itself. Pineapple juice, which the patient consumed daily, contains bromelain, a substance that can inhibit cytochrome P450 2C9, ${ }^{6}$ which is the main metabolic pathway for acetylsalicylic acid. ${ }^{7}$ Therefore, regular intake of pineapple juice could have been an additional factor leading to higher exposure to salicylates.

All of this would contribute to increase the effects of salicylates on both platelet aggregation and blood pressure.

Hypoprothrombinaemia may have also been increased by omega- 3 fatty acids, as the patient was consuming large doses of DHA. ${ }^{8}$

Furthermore, liquorice has been reported to reduce the effects of the antihypertensive medication by increasing liquid retention. ${ }^{9}$

In this case, none of these products would have been considered dangerous on their own, as they are consumed by a large amount of people without incident. They would have been overlooked unless the personalised prescribing software had reported them as potential risks of interaction 


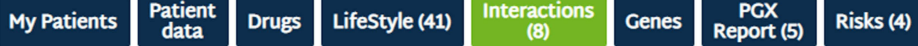

\begin{tabular}{|c|c|}
\hline Interactions Drug/Dru & ind Drug/Lifestyle \\
\hline Name & Med.history Num/Ref. \\
\hline Active ingredient & Category interaction (i) Drug/Lifestyle interaction (i) Drug/Drug interaction (i) \\
\hline $\begin{array}{l}\text { Metformin } \\
\text { Telmisartan }\end{array}$ & $\begin{array}{l}\text { (1) } \\
\text { Angiotensin II receptor inhibitors may increase the effect of hypoglycemic agents and facilitate } \\
\text { hypoglycaemia. } \\
\text { MANAGEMENT OPTIONS: Blood glucose concentrations should be monitored more carefully at the } \\
\text { beginning or the end of a concomitant treatment. } \\
\text { Ref: Toujeo (insulin glargine) [FDA product information] 03/2018 }\end{array}$ \\
\hline $\begin{array}{l}\text { Empagliflozin } \\
\text { Telmisartan }\end{array}$ & $\begin{array}{l}\text { (1) } \\
\text { Angiotensin II receptor inhibitors may increase the effect of hypoglycemic agents and facilitate } \\
\text { hypoglycaemia. } \\
\text { MANAGEMENT OPTIONS: Blood glucose concentrations should be monitored more carefully at the } \\
\text { beginning or the end of a concomitant treatment. } \\
\text { Ref: Toujeo (insulin glargine) [FDA product information] 03/2018 }\end{array}$ \\
\hline $\begin{array}{l}\text { Acetylsalicilic acid } \\
\text { Telmisartan }\end{array}$ & $\begin{array}{l}\text { 1 } \\
\text { NSAIDs reduce the efficacy of antihypertensive drugs because they reduce the renal function. The effect } \\
\text { is gradual and therefore if the use of NSAIDs in the short term it is unlikely to have clinically relevant } \\
\text { consequences. } \\
\text { MANAGEMENT OPTIONS: The risk of interaction can be minimized by using acetaminophen instead of } \\
\text { an NSAID, using nonacetylated salycilates instead of an NSAID or using the NSAID at low doses and for } \\
\text { the shortest possible time. During a combined therapy, it is warranted to monitor blood pressure. }\end{array}$ \\
\hline $\begin{array}{l}\text { Ginger (Zingiber } \\
\text { officinale) } \\
\text { Metformin }\end{array}$ & $\begin{array}{l}\text { i } \\
\text { Both ginger and metformin can increase insulin levels and/or lower blood glucose levels, which by } \\
\text { additive effect can lead to hypoglycemia. } \\
\text { MANAGEMENT OPTIONS: In the concomitant use, it is recommended to monitor blood glucose levels } \\
\text { more closely. } \\
\text { Ref: } \\
\text { Zadoyan G, Fuhr U. Phenotyping studies to assess the effects of phytopharmaceuticals on in vivo } \\
\text { activity of main human cytochrome p450 enzymes. Planta Med. } 2012 \text { Sep;78(13):1428-57. }\end{array}$ \\
\hline Bisoprolol & $\begin{array}{l}\text { (i) } \\
\text { Licorice can cause fluid retention and reduce the effect of antihypertensives. } \\
\text { MANAGEMENT OPTIONS: It is recommended to avoid the concomitant use of antihypertensive with } \\
\text { licorice, even in infusion doses. }\end{array}$ \\
\hline $\begin{array}{l}\text { Licorice (Glycyrrhiza } \\
\text { glabra) }\end{array}$ & $\begin{array}{l}\text { Ref: Stockley, Ivan H. Stockley's Herbal Medicines Interactions. A guide to the interactions of herbal } \\
\text { medicines, dietary supplements and nutraceuticals with conventional medicines. Great Britain: } \\
\text { Pharmaceutical Press; 2009. p273 }\end{array}$ \\
\hline $\begin{array}{l}\text { Acetylsalicilic acid } \\
\text { Clopidogrel } \\
\text { Ginger (Zingiber } \\
\text { officinale) }\end{array}$ & $\begin{array}{l}\text { I } \\
\text { It has been reported that ginger (Zingiber officinale) inhibits the thromboxane synthetase activity with } \\
\text { which it can interact with anticoagulants in a significant way. } \\
\text { MANAGEMENT OPTIONS: It is recommended to avoid the association and, if necessary, monitor the INR } \\
\text { more closely. } \\
\text { Ref: } \\
\text { Tsai HH et al. A review of potential harmful interactions between anticoagulant/antiplatelet agents and } \\
\text { Chinese herbal medicines. PLoS One. } 2013 \text { May } 9 ; 8(5): e 64255 \text {. }\end{array}$ \\
\hline $\begin{array}{l}\text { Acetylsalicilic acid } \\
\text { Clopidogrel } \\
\text { Omega } 3 \text { fatty acids }\end{array}$ & $\begin{array}{l}\text { (A) } \\
\text { The administration of omega-3 ethyl esters with antiplatelet drugs result, by a sinergic effect, in a } \\
\text { potentation in the action of antiplatelet agents. } \\
\text { MANAGEMENT OPTIONS: Watch for signs of excessive platelet antiaggregation. } \\
\text { Cohen MG, Rossi JS, Garbarino J et al. Insights into the inhibition of platelet activation by omega-3 } \\
\text { polyunsaturated fatty acids: beyond aspirin and clopidogrel. Thromb Res. } 2011 \text { Oct;128(4):335-40. }\end{array}$ \\
\hline $\begin{array}{l}\text { Acetylsalicilic acid } \\
\text { Blueberry (Vaccinium } \\
\text { corymbosum, v. } \\
\text { myrtillus) }\end{array}$ & $\begin{array}{l}\text { (1) } \\
\text { Long-term consumption of cranberry juice in large quantities (approximately } 1 \mathrm{~L} / \text { day or more), as well as } \\
\text { blueberry concentrate supplements, can potentiate the action of aspirin. There is no evidence that } \\
\text { coagulation is affected to a clinically relevant extent with daily consumption of up to half a liter. } \\
\text { MANAGEMENT OPTIONS: Due to the narrow therapeutic index of aspirin, it is prudent that the } \\
\text { consumption of cranberry juice is rather low when using this drug. } \\
\text { Ref: Srinivas NR. Cranberry juice ingestion and clinical drug-drug interaction potentials; review of case } \\
\text { studies and perspectives. J Pharm Pharm Sci. 2013;16(2):289-303. }\end{array}$ \\
\hline
\end{tabular}

Figure 3 Drug interactions and drug - lifestyle reported by the personalized prescription software. 


\begin{tabular}{|c|c|c|c|c|}
\hline \multicolumn{2}{|l|}{ Name } & \multicolumn{2}{|r|}{ Surname } & Med.history Num/Ref. Patient \\
\hline $\begin{array}{l}\text { Active } \\
\text { ingredient }\end{array}$ & $\begin{array}{l}\text { Brand name } \\
\text { drug }\end{array}$ & $\begin{array}{l}\text { Evidence } \\
\text { icon }\end{array}$ & Gene & Relevant information \\
\hline $\begin{array}{l}\text { Pineapple - } \\
\text { juice }\end{array}$ & & & CYP2C9 & $\begin{array}{l}\text { Pineapple -juice is a potent inhibitor of the CYP2C9 enzyme, so the } \\
\text { bioavailability of Acetylsalicilic acid may be increased by a factor greater } \\
\text { than 5. It is recommended to replace Pineapple -juice, with another of } \\
\text { similar effect that is not a potent enzyme inhibitor CYP2C9 to avoid } \\
\text { toxicity due to overdose, except when there are guidelines that define the } \\
\text { dose reduction for this drug. }\end{array}$ \\
\hline $\begin{array}{c}\text { Licorice } \\
\text { (Glycyrrhiza } \\
\text { glabra) }\end{array}$ & & & $\begin{array}{l}A B C B 1 \\
C Y P 3 A 4\end{array}$ & $\begin{array}{l}\text { (1) } \\
\text { Being Licorice (Glycyrrhiza glabra), weak inducer of the efflux transport } \\
\text { protein Pgp -MDR1, encoded by the gene ABCB1, a slightly lower plasma } \\
\text { levels of expected will be achieved of the drugs Atorvastatin, so it would be } \\
\text { recommended to increase the dose by } 20-30 \% \text {. It is difficult to generalize } \\
\text { and must see if there is specific information for each drug on drug } \\
\text { monographs. } \\
\text { B } \\
\text { gecause Licorice (Glycyrrhiza glabra) is a weak inducer of the CYP3A4 } \\
\text { gene/s, it can accelerate the metabolism of drugs that are substrates of it, } \\
\text { l.e. Clopidogrel*. Being a prodrug/s, its transformation to the active form } \\
\text { can be accelerated. Usually this has no negative effects. However, if the } \\
\text { pathway that is induced is purely for elimination and does not contribute to } \\
\text { the formation of active metabolites, the result would instead be a reduced } \\
\text { efficacy. In some cases accelerated bioactivation can lead to overdose } \\
\text { peaks. It is recommended to check the specific messages for more } \\
\text { complete information. } \\
\text { Since Licorice (Glycyrrhiza glabra) is/are weak inducer/s of the gene CYP3A4 } \\
\text { it may accelerate the metabolism of drugs that are substrates of it: } \\
\text { Atorvastatin, Bisoprolol. Therefore it will require higher doses to achieve } \\
\text { the same therapeutic effect. It is recommended to increase the dose by 20- } \\
30 \% \text {. }\end{array}$ \\
\hline $\begin{array}{l}\text { Acetylsalicilic } \\
\text { acid }\end{array}$ & & & CYP2C19 & $\begin{array}{l}\text { (1) } \\
\text { Because Acetylsalicilic acid is a weak inducer of the CYP2C19 gene/s, it can } \\
\text { accelerate the metabolism of drugs that are substrates of it, i.e. } \\
\text { Clopidogrel*. Being a prodrug/s, its transformation to the active form can } \\
\text { be accelerated. Usually this has no negative effects. However, if the } \\
\text { pathway that is induced is purely for elimination and does not contribute to } \\
\text { the formation of active metabolites, the result would instead be a reduced } \\
\text { efficacy. In some cases accelerated bioactivation can lead to overdose } \\
\text { peaks. It is recommended to check the specific messages for more } \\
\text { complete information. }\end{array}$ \\
\hline & & & & 8 \\
\hline
\end{tabular}

Figure 4 Pharmacogenetics interactions described by the personalized prescription software.

with the patients' medication. The proactive warning prompted the physician to ask the patient about the consumption of these products. Herbal products or extracts used as supplements, such as blueberry extracts, would perhaps have been considered at some point, while consumption habits, such as pineapple juice, would have remained unnoticed.

No specific cause of the fatigue was identified with certainty, but it was likely to be a side effect of the blood loss. 


\section{My Patients Patient}

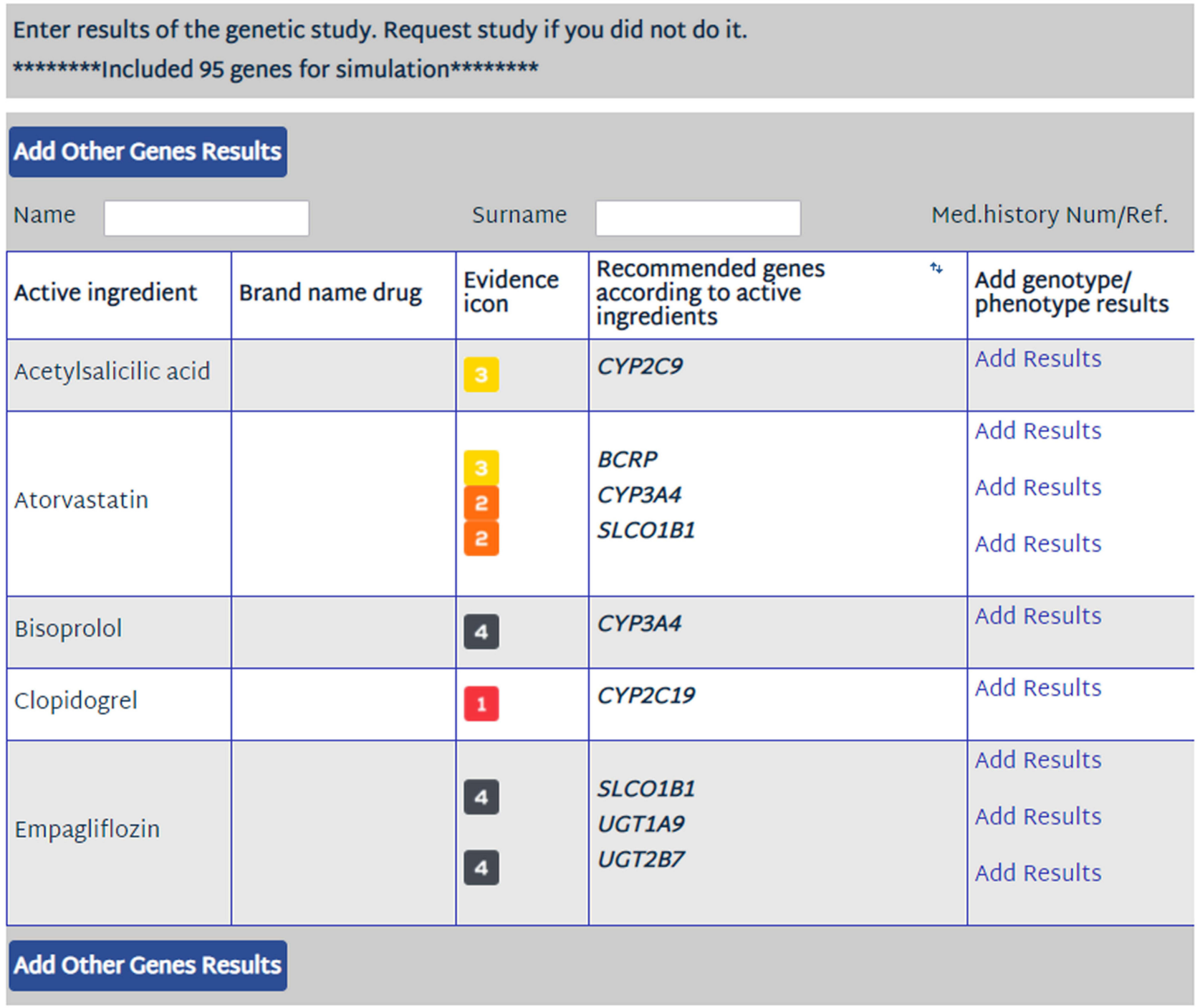

Figure 5 Pharmacogenetics markers described by the personalized prescription software.

In this case, the extracts the patient used, containing blueberry and ginger, could have contributed to bleeding, in addition to DHA and pineapple juice. These substances in combination were considered a likely trigger for the gingival bleeding. ${ }^{9}$ It is not possible to know the relative contribution of these substances to the interaction, nor if a clinically meaningful interaction would still have happened without the presence of the whole polymedication. Caution is recommended whenever natural products are used in combination with drugs affecting haemostasis.

The patient's condition improved as the drug regimen was reduced and simplified, meaning that some drugs may have been unnecessary in the first place. For example, the hypertension could have been secondary to the use of liquorice and salicylate potentiation, and in this case, discontinuation of these substances would have been more helpful in controlling blood pressure than starting telmisartan.

\section{Conclusion}

This case report serves to illustrate two concepts: I) the importance of recognizing the interactions of existing compounds in commonly consumed products, in this particular case with anticoagulants. It is therefore advisable to use drug interaction software that take into account lifestyle habits. II) 
Be aware of the increased risk of drug-drug interactions in patients consuming multiple natural products not considered drugs, which may be the cause of many drug-drug interactions. While being aware of the dangers of polymedication with multiple therapeutic drugs, other substances such as herbal products and dietary supplements, should not be disregarded. Reducing the drug regimen may occasionally lower the amount and severity of drug interactions, provided that the remaining drugs are enough to control the pathology. This work emphasizes the need for personalized approaches for patient empowerment in both clinical settings and home health care.

\section{Consent Form}

Consent was obtained from the patient to allow publication of his medical record. The patient was informed that his case of polymedication would be presented as a case report to the scientific community in order to let other healthcare professionals know what his treatment was like and how it has evolved.

The patient signed a consent form to authorise his doctor to record his medical history for the purpose of a scientific publication on his health conditions. He agreed to have his medical records recorded for the named purpose of a scientific publication. No ethics statement from the institution was required, the sole statement from doctor was needed.

\section{Disclosure}

Marc Cendrós and Ana Sabater work for EUGENOMIC S. L. and are directly involved in the development of the g-Nomic ${ }^{\circledR}$ the personalized prescription software, but neither they nor anyone at Eugenomic has had any role in the management and clinical evaluation of this case beyond assisting the medical professionals in using the software. In addition, Mrs Ana Sabater has a patent g-Nomic issued to Eugenomic. The authors declare no other conflicts of interest in this work.

\section{References}

1. Nikolic B, Jankovic S, Stojanov O, Popovic J. Prevalence and predictors of potential drug-drug interactions. Cent Eur J Med. 2014. doi:10.2478/s11536-013-0272-4

2. McQuaid KR, Laine L. Systematic review and meta-analysis of adverse events of low-dose aspirin and clopidogrel in randomized controlled trials. Am J Med. 2006;119(8):624-638. doi:10.1016/j. amjmed.2005.10.039

3. Sabater A, Ciudad CJ, Cendros M, Dobrokhotov D, Sabater-Tobella J. G-nomic: a new pharmacogenetics interpretation software. Pharmgenomics Pers Med. 2019. doi:10.2147/PGPM.S203585

4. Tsai HH, Lin HW, Lu YH, Chen YL, Mahady GB. A review of potential harmful interactions between anticoagulant/antiplatelet agents and chinese herbal medicines. PLoS One. 2013. doi:10.1371/ journal.pone.0064255

5. Srinivas NR. Cranberry juice ingestion and clinical drug-drug interaction potentials; review of case studies and perspectives. J Pharm Pharm Sci. 2013;16(2):289. doi:10.18433/j3ng6z

6. Hidaka M, Nagata M, Kawano Y, et al. Inhibitory effects of fruit juices on cytochrome P450 2C9 activity in vitro. Biosci Biotechnol Biochem. 2008;72(2):406-411. doi:10.1271/bbb.70511

7. Agundez J, Martinez C, Perez-Sala D, et al. Pharmacogenomics in Aspirin Intolerance. Curr Drug Metab. 2009;10(9):998-1008. doi:10.2174/138920009790711814

8. Cohen MG, Rossi JS, Garbarino J, et al. Insights into the inhibition of platelet activation by omega-3 polyunsaturated fatty acids: beyond aspirin and clopidogrel. Thromb Res. 2011;128(4):335-340. doi:10.1016/j.thromres.2011.04.023

9. Stockley's herbal medicines interactions: a guide to the interactions of herbel medicines, dietary supplements and nutraceuticals with conventional medicines. Choice Rev. 2010. Availble form: https://www.access data.fda.gov/drugsatfda_docs/label/2016/204353s0201bl.pdf. Accessed August 2, 2021. doi:10.5860/choice.47-2357
Pharmacogenomics and Personalized Medicine

\section{Publish your work in this journal}

Pharmacogenomics and Personalized Medicine is an international, peer-reviewed, open access journal characterizing the influence of genotype on pharmacology leading to the development of personalized treatment programs and individualized drug selection for improved safety, efficacy and sustainability. This journal is indexed on the American Chemical Society's Chemical Abstracts Service (CAS). The manuscript management system is completely online and includes a very quick and fair peer-review system, which is all easy to use. Visit http://www.dovepress.com/testimonials.php to read real quotes from published authors. 